\title{
PRE-QUATERNARY GEOMORPHOLOGICAL HISTORY AND GEOHERITAGE OF BRITAIN
}

\author{
Piotr Migoń \\ Department of Geography and Regional Development, University of Wrocław, Wrocław, Poland \\ ANDREW GOUdiE \\ China Centre, University of Oxford, Oxford, U.K.
}

Manuscript received: January 18, 2012

Revised version: March 12, 2012

\begin{abstract}
Migoń, P. \& Goudie A., Pre-Quaternary geomorphological history and geoheritage of Britain. Quaestiones Geographicae 31(1), Bogucki Wydawnictwo Naukowe, Poznań 2012, pp. 67-79. 9 Figs. DOI 10.2478/v10117-012-0004-x, ISSN 0137-477X.

ABSTRACT. Substantial parts of the British Isles preserve landscapes that are the legacy of pre-Quaternary times. Some of these may be the result of burial and exhumation of pre-Cenozoic features. However, most landscapes post-date the Cretaceous transgression during which a Chalk mantle was laid down. Much of the British Isles became land during the Palaeogene and the Chalk cover was rapidly removed over large areas. Sea floor spreading, thermal uplift, and intrusion and extrusion of igneous material occurred. Landscapes also evolved in response to warm climatic conditions and this may have led to etchplanation. In the Neogene various surface formed and were affected by ongoing tectonic activity. Various estimates have been made of Cenozoic denudation rates and amounts, but they appear to have varied spatially and temporally. Landscapes which provide tangible evidence of pre-Quaternary times include those of north-east Scotland and southern England. Such ancient landscapes are important components of the Geoheritage of Britain.
\end{abstract}

KEY wORDS: geoheritage, long-term landform development, Cenozoic, Britain

Piotr Migon, Department of Geography and Regional Development, University of Wroctaw, pl. Uniwersytecki 1, 50-137 Wrockaw, Poland, e-mail: piotr.migon@uni.wroc.pl

\section{Introduction}

Geoheritage and geotourism are intimately linked together. Perspectives for the development of the latter increase if the former is rich, diverse and scenic. However, looking at prevailing contemporary approaches to both one can find an apparent divergence of focuses. On the one hand, geoheritage and its potential for geotourism is usually evaluated in terms of geosites, i.e. individual localities at which rocks, structures, record of past life, and landforms can be seen and interpreted. Consequently, geoheritage literature abounds in examples of geosite inventories and assessments. The focus on geosites can be contrasted with the observation of Newsome and 
Dowling (2005) that it is whole landscapes that are likely to generate most interest, rather than more specialized themes such as rock types, soils or minerals. The natural physical scenery is not only appealing to an eye, even untrained (unless it is completely flat or obscured by dense vegetation), but it tells complex stories of landscape evolution by erosion and, less often, by deposition. Therefore, it is as much a part of geoheritage as individual geosites. These stories can be traced far back in time and it has been demonstrated from many places around the world that erosional landscapes can be of distant, pre-Quaternary, and even pre-Cenozoic age (e.g. Ollier 1991, Twidale 1997, Rabassa et al. 2011). Properly explained, such ancient landscapes may become a significant resource for geotourism, offering easily accessible windows into the past.

In this paper we want to focus on the preQuaternary geomorphological history of the British Isles (Fig. 1) and demonstrate that, despite successive glaciations, substantial parts of the British landscape are the legacy of those distant

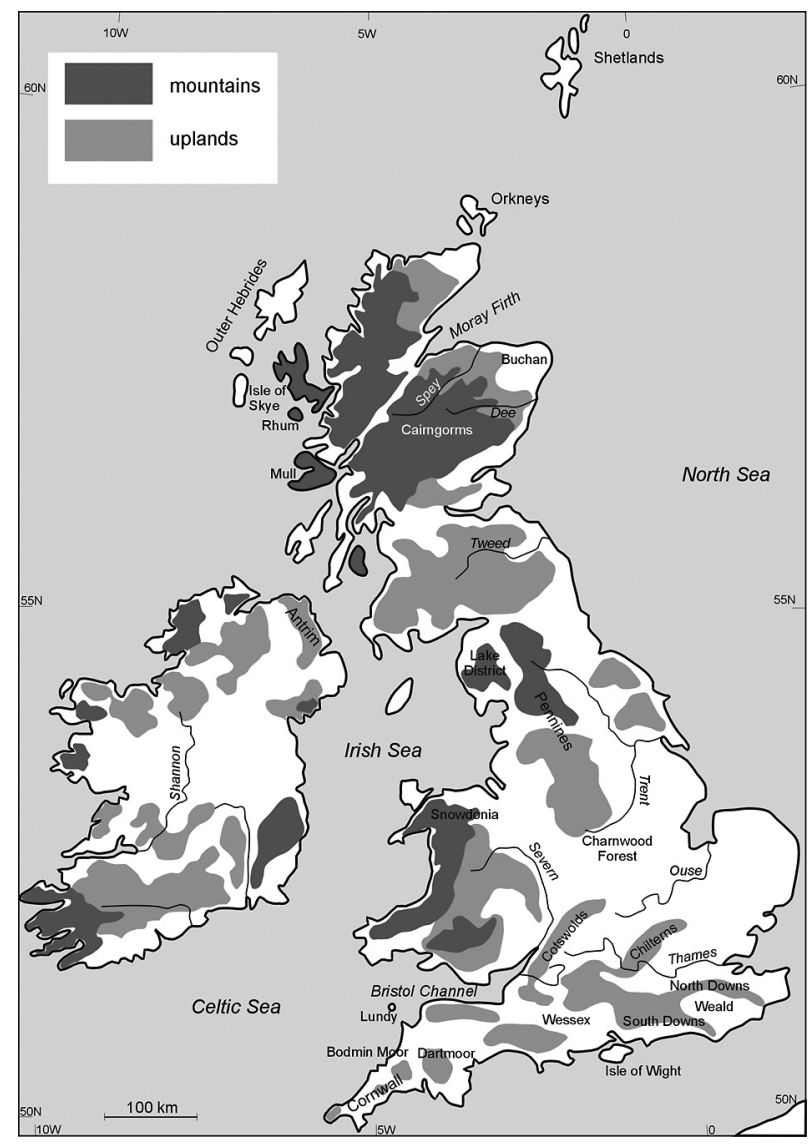

Fig. 1. Location map and the distribution of mountain and upland terrain in the British Isles. times. In addition, they fill a gap in our encounters with Earth history. While individual localities, often designated as Sites of Special Scientific Interest, cover mostly Palaeozoic and Mesozoic history (as rocks and fossil localities), or the relatively recent Pleistocene (glacial and periglacial landforms), the gross features of relief are inherited from the Palaeogene and Neogene and are the cumulative product of long-term changes in climate, sea-levels and tectonic activity. Being remarkably varied, they contribute greatly to geoheritage and must not be ignored.

\section{Pre-Cenozoic landforms}

Pre-Cenozoic (pre-Tertiary) landforms are important in some areas of the world but in the British Isles this is not the case. Indeed Brown (1979, p. 460) has gone so far as to state: It is highly unlikely that any facet of the present surface of Britain has been inherited from pre-Tertiary times. Nothing as old as 63,000,000 years could possibly have survived intact without burial and exhumation; even surfaces having little or no slope would at least have suffered substantial lowering by chemical denudation.

The caveat that some landforms might be present today as a result of 'burial and exhumation', is, however, important. This is particularly true with respect to the existence of possible exhumed Triassic landscapes of dryland type. The classic location for landforms of this genre, though by no means the only one, is Charnwood forest in the East Midlands of England, as was noted by Watts (1903). Another area where exhumation has been suggested as a cause of exposure of Triassic landscapes is Wales, where Jones (1931) postulated that the widespread upland plateau surfaces may represent an ancient Triassic peneplain which owes its remarkable preservation both to the resistance of the underlying Palaezoic rocks and to its subsequence protection beneath Mesozoic strata. Further possible examples have been cited by Hall \& Bishop (2002) from the fringes of the Scottish Highlands and include the rugged sub-Torridonian surface in NW Scotland cut across Proterozoic gneiss and the sub-Devonian surface around the Moray Firth. It is also likely that certain landscape facets of the Buchan surface in NE Scotland, including 
some of its inselbergs, are of late Mesozoic age and have been exhumed from beneath the blanket of Cretaceous chalk (Hall 1987).

Equally, there may be many individual landforms of karstic origin that have been exhumed, some of which may be even of Carboniferous age (Wright 1986) and include certain gorges (Ford 1986), such as the famous Winnats Gorge in the Peak District, and solution pits (Vincent 1995).

\section{The Cretaceous transgression}

In the Late Cretaceous (c. 70-100 million years ago), the Chalk was laid down. It is an extremely pure marine limestone that accumulated in the North Sea Basin to a thickness of up to 886 m (Hancock 1975, Gale 2000). It is probable that when it was deposited Britain, with the possible exception of a few islands in high-altitude locations, suffered almost total submergence (Fig. 2). This submergence probably caused severe marine planation of underlying structures before the Chalk was deposited, and the subsequent deposition of a thick cover of Chalk on top of this marine unconformity effectively sealed off the past.

Relicts of this almost total blanket of Chalk occur as remnant outliers in Ireland and parts of the English West Country, and as major exposures in southern and eastern England. There is, however, some debate as to how extensive the Chalk cover was, particularly in Wales. Battiau-Queney (1984) has posed the question that if Chalk was extensive over Wales why it is that no residual deposits (especially flints) have been found, either on the surface or, particularly, in karstic pockets or pipes? On the other hand, widespread distribution of chalk-derived flints in till across Ireland points to their almost complete submergence by the end of Mesozoic (Allen et al. 2002).

When the Chalk sea retreated as a result of tectonic uplift and eustatic sea-level change, a new-land area became exposed. On this a consequent drainage system developed comprising many large rivers, which drained primarily towards the present North Sea. The Chalk cover has subsequently been stripped from large areas but the drainage pattern developed on it has probably been superimposed on to the underlying Mesozoic and Palaeozoic rocks (Linton 1951,

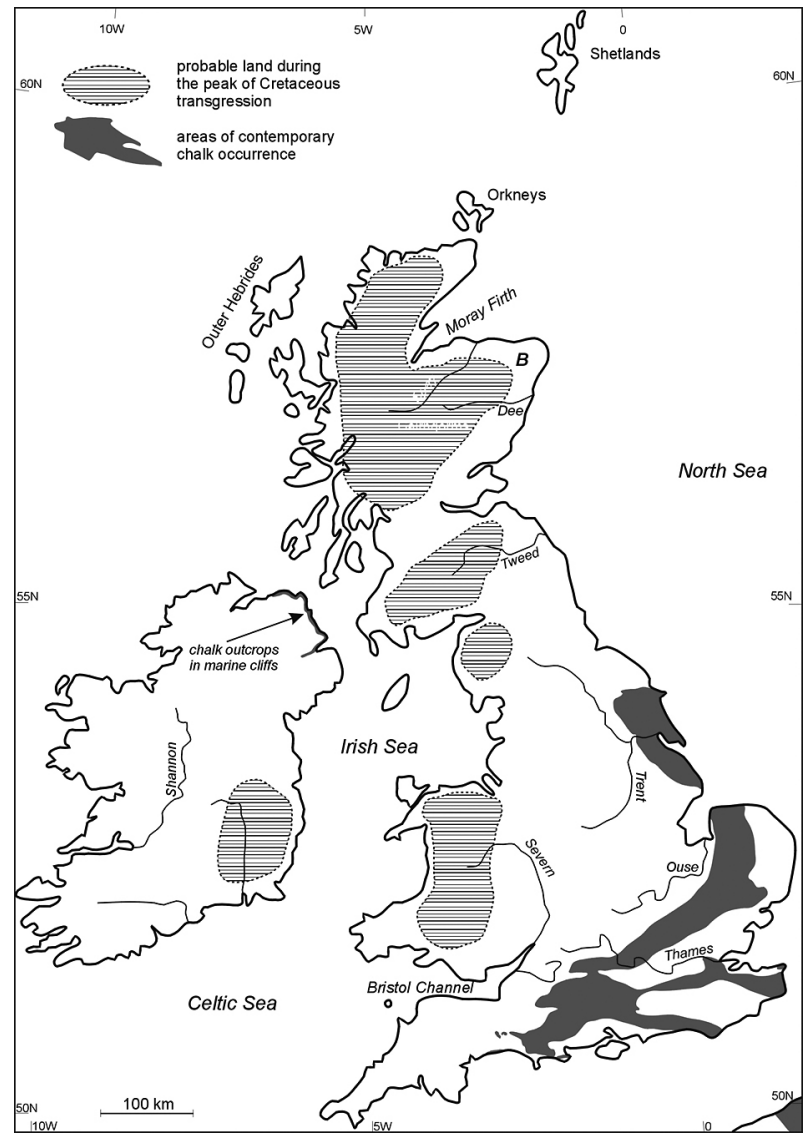

Fig. 2. The probable extent of Late Cretaceous transgression in the British Isles (after Gale 2000) and the current occurrence of chalk deposits. B - Buchan surface, where the presence of exhumed Mesozoic landforms is suspected.

Small 1970). The latest addition to the subject was by Cope (1994) who argued for a late Cretaceous domal uplift centred upon the Irish Sea and consequent inception of a radial drainage over the southern part of the British Isles, originally on the chalk blanket and later on the underlying rocks. The problem with the concept of drainage superposition is that it may be attractive and logical, but is very difficult to prove.

\section{The Palaeogene tectonic setting}

The Cretaceous was succeeded by the various periods of the Cenozoic, and it is within this period when the main geomorphological features of the British Isles have developed. The significance of the pre-Quaternary times has been long recognized, e.g. by Wooldridge \& Linton (1955, p.1) who wrote in their classic study: The shaping of the British landscape has been the work of Tertiary times, 
a period now indicated, by radioactive dating, as having a duration of some 65-70 millions of years. In this long interval the mountains were shaped, the valleys carved, and the coastlines developed to their present form. It is in this sense that Tertiary time in Britain means more for geomorphology than for stratigraphical geology. The story of sedimentation is scant, but the interval of time represented is vast, vast enough for the evolution of the whole British landscape as we know it.

Indeed, much of the British Isles became land during the early Palaeogene and has remained land ever since. The unresistant blanket of Chalk probably suffered rapid attack (Cope 1994) and was removed over large areas at a relatively early date. In south-west England the Bovey formation of Eocene - Oligocene age provides useful evidence for reconstructing the Palaeogene geomorphological environment (Green 1985). It contains kaolinitic clays derived from the weathering of granite and Palaeozoic sediments, indicating that the basement rocks were extensively exposed in Eocene times. Likewise, although Chalk-derived flint is a major component of the Upper Palaeocene Reading Beds, their clay mineralogy and pebble content indicate that the underlying basement rocks of south-west England were exposed in Reading Beds times. In the northern part of Ireland Early Palaeogene basaltic lava flows locally rest directly on pre-Cretaceous bedrock, although it is known that a few hundreds meters of Late Cretaceous Chalk was deposited there (Wilson 1972). These circumstances point to very rapid denudation of the Chalk after land emergence at the turn of the Cenozoic, probably at rates approaching $100 \mathrm{~m} / \mathrm{Ma}$. After the Chalk had been removed, mainly through solution, denudation was able to attack underlying lithologies, and to contribute debris to the thick sedimentary sequences that accumulated in the North Sea, London and Hampshire Basins, and in the faultcontrolled basins that developed in the west (e.g. Bovey Tracey, Petrockstow, the Celtic Sea, the British Channel and Cardigan Bay).

The post-Cretaceous time was also a period when sea-floor spreading had advanced sufficiently that an opening was appearing between Ireland and Greenland. This phase of plate separation commenced with a major thermal uplift, probably more than $2000 \mathrm{~km}$ across (Nadin et al., 1995; Anderton 2000). Associated with it was a severe spasm of intrusion and extrusion of igneous material which lasted from 61 to 52 million years ago (Dewey \& Windley 1988). Flood basalts were erupted to give lava sheets, notably on Mull in western Scotland (where they are some 2000 $\mathrm{m}$ in thickness), in the Isle of Skye, and in Antrim, Northern Ireland, where they still cover c. $3800 \mathrm{~km}^{2}$ and support contemporary tableland topography. At roughly the same time igneous intrusions developed in north-west Scotland and north-east Ireland. Further to the south, the Lundy granites of the Bristol Channel were emplaced at some 52 million years ago. Most of this activity had ceased by the early Eocene, for as the Atlantic continued to open igneous activity shifted westwards and became centred upon the location that was eventually to become Iceland.

In roughly the same period, landscape evolution in the southern part of contemporary Britain was influenced by the collision of Africa and Europe, which began in the late Mesozoic. It created compressional forces that caused a major orogenic phase culminating in the evolution of the Pyrenees and the Alps, but its distant effects reached as far as southern Britain. This tendency reached its climax during the late Eocene and early Oligocene, when inversion tectonics took place causing the development of the Weald and Purbeck - Isle of Wight anticlinal structures (Jones 1999b, Blundell 2002). In addition, widespread faulting occurred, frequently rejuvenating pre-existing ancient structures and causing broad warpings of the crust. However, it is not entirely clear that these foldings, faultings and warpings necessarily have an 'Alpine' pedigree. As Anderton et al. (1979, p. 255) suggest: They could reflect crustal readjustments following the Palaeocene departure of Greenland due to sea floor spreading. In any case, "Alpine" effects in Britain were probably magnified as a result of early Tertiary Atlantic opening.

In addition, as Jones (1999a) has pointed out, southern Britain was effectively compartmentalised into a number of structural units each of which had a different tectonic history that may have been related to movements of sub-surface faults and deeply buried thrusts in the Palaeozoic Floor/Variscan Basement. The same has been suggested by Battiau-Queney $(1984,1999)$ with respect to Wales. The recent reconstruction 
of denudational history of Ireland based on apatite fission-track dating shows marked regional differences and likewise suggests that, at least in Paleocene - Eocene times, fault blocks or geological compartments reacted like piano keys to a regional tectonic event (Allen et al. 2002, p. 396).

\section{Palaeogene climates}

Notwithstanding the impact of tectonics, it is indisputable that geomorphological evolution is also controlled by environmental factors, of which climatic parameters play the supreme role. Therefore, examination of the nature of the Palaeogene climates in Britain becomes crucial for reconstruction of landforming processes.

The general picture is that the Palaeogene was the period of warmth. The prime evidence for tropical conditions in Britain is provided by plant remains in Tertiary sediments. The classic interpretation was that of Reid \& Chandler (1933), who believed that the early Eocene London Clay flora compared most suitably with the presentday vegetation of the Indo-Malayan region. However, as Daley $(1972$, p. 187) has pointed out, Such a climate, with its markedly uniform character throughout the year, could not have existed at the latitude of southern Britain during the Eocene $\left(40^{\circ} \mathrm{N}\right)$, since seasonal climatic variations would undoubtedly have occurred. Daley envisages that given frostfree conditions and high rainfall levels tropical plants may have become established in low-lying damp areas even though temperatures were not truly tropical. Nevertheless the picture of early and middle Eocene warmth was confirmed by later studies (Creber \& Chaloner 1985; Collinson \& Hooker 1987). Further confirmation of the existence of Eocene warmth comes from the isotopic evidence obtained from cores in the North Sea and elsewhere (Buchardt, 1978).

Another source of information on climates is provided by fossil soils in the Palaeocene Reading Beds. At Alum Bay, on the Isle of Wight, 'a warm climate with a marked dry season' is suggested (Buuman 1980). Features of weathering horizons, particularly on basalt flows, and terrestrial deposits such as silcretes are less conclusive, but they also indicate climate which was significantly warmer than today.

\section{Possible mechanisms of landscape development in the Palaeogene}

In the last few decades a possible specific mechanism for surface development in the warm and humid conditions of the Palaeogene has been recognized. It has become known as etchplanation and involves, in its simplest form, a combination of deep chemical decomposition of bedrock followed by effective surface wash under tropical conditions with a long rainy season (6-9 months). In certain circumstances, such as extremely intense weathering or little differentiated bedrock, a planation surface with residual hills, an inselberg-studded etchplain, is the end-form. The concept of etchplanation was developed in the Tropics, but it has been used subsequently to explain the origin of pre-Quaternary surfaces in Europe as well. The prime champion of this mechanism was a German geomorphologist, J. Büdel (1957), who also maintained that the Pleistocene had only lightly overprinted the basic relief shaped under tropical conditions. In the British context, the usefulness of the etchplanation concept to explain landform origin was first outlined by Thomas (1978). Environmental conditions favourable to etchplanation have also been championed by Battiau-Queney (1984), most notably in the context of Wales, then by Hall (1987) with reference to Scotland, and more recently by Jones (1999a) and Walsh et al. (1999) for southern England.

The validity of the etchplanation concept is supported by relict deep weathering phenomena present in many parts of the British Isles and duricrusts of possible tropical of subtropical type which occur in association with Palaeogene beds. These include the silcretes of southern England (Summerfield \& Goudie 1980; Fig. 3) and the well-developed ferruginous weathering horizons and bauxites of the Antrim Plateau in Northern Ireland (Smith \& McAlister, 1987; Hill et al. 2001). The latter merit particular attention as they testify to very rapid, deep and thorough decomposition. Deep weathering profiles of a thickness up to $15 \mathrm{~m}$ have probably formed in less than $1 \mathrm{Ma}$. In North Wales and Derbyshire the Mio-Pliocene Brassington formation consists of pockets of what appear to be products of tropical weathering (Walsh et al. 1972), while in 


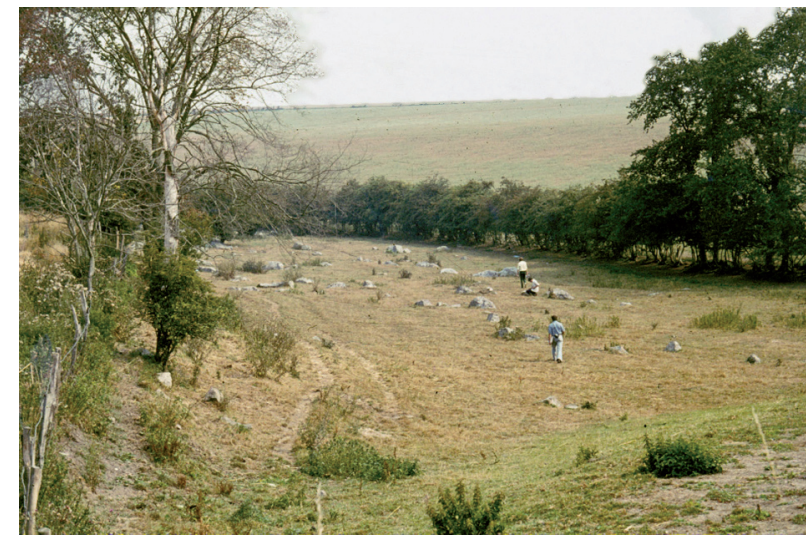

Fig. 3. Sarsen stones scattered across the chalk surface in Wiltshire (photo by Andrew Goudie).

Cornwall Walsh et al. $(1987,1999)$ believe they have identified pockets of Miocene saprolite on an etchplain of tropical and subtropical origins. Similarly, Battiau-Queney (1984) claims to identify inselbergs, tropical planation surfaces and tropical weathering products in Wales. In East Devon Isaac (1983) has attributed the Plateau Deposits to lateritic deep weathering in the early Tertiary. Kaolinitic ball clays are widespread in south-west England, and these too are thought to form most effectively under hot and wet conditions. Finally, the famous kaolinitic China clay deposits of Dartmoor, Bodmin Moor and St Austell owe their origin to effective deep weathering in the Early Cenozoic (Bristow 1977, Sheppard 1977, Bristow \& Exley 1994), although pre-conditioning of rock by hydrothermal activity may also have played an important part (Bristow 1977, Durrance et al. 1982).

Stripping of weathering mantles in the Palaeogene, the second important component of etchplanation, can also be demonstrated by examination of contemporaneous sediments. Eocene-Oligocene deposits in the fault-bounded basins in SW England consist of large thicknesses of re-deposited products of kaolinitic weathering (Edwards \& Freshney 1982). Likewise, Palaeogene to Miocene sediments around the Scottish landmass contain kaolinite and indicate stripping of weathering covers (Hall, pers. comm.).

\section{The Neogene}

It has for long been believed that the higher summits of central, southern and south-eastern
England show a marked degree of accordance in the height range 230-260 $\mathrm{m}$ (Davis 1895). Wooldridge \& Linton (1955) thought this was a surface produced by a Mid-Tertiary cycle of subaerial peneplanation which occurred after the Alpine pulse of uplift, and which planed off folded terrain. This hill-top peneplain was thought to be largely horizontal and to transect the Alpine folds. It was also thought not to have been seriously modified by any subsequent warpings except near the coastline of East Anglia bordering the North Sea basin. Since they believed that the Alpine folding occurred in the late Oligocene and early Miocene, they attributed the peneplain to a period of crustal stability in the Neogene (late Miocene and early Pliocene). One classic area which Wooldridge and Linton (1955) identified for this feature was in the Chalk uplands of Wessex. Wooldridge (1952) noted that a plane 800 feet $(240 \mathrm{~m})$ above sea-level would pass close to many of the summits of southern England. He believed that the Cotswold summits (e.g. Cleeve Hill and Broadway Hill) might also be remnants of the great mid-Tertiary plain. Subsequently, others identified the alleged surface elsewhere in Britain. Clayton (1953) correlated it with the 1,000-foot' $(300 \mathrm{~m})$ surface of the southern Pennines, and Brunsden (1963) with the lower surface of Dartmoor (230-280 m). Correlation was based on height, and the possibility of continuing tectonic differentiation between different parts of England and Wales was largely ignored.

More recently doubt has been thrown on this interpretation (Jones 1999a), largely because current work recognizes that the tectonic evolution of southern Britain in the Cenozoic was significantly more complex. The concept of a brief and intense Alpine storm, responsible for the main fold-structures, is seen to be an oversimplification. Thus Jones (1981, p.27) argued that: The increasingly numerous reports of the survival of Palaeogene sediments and surfaces on the higher chalklands casts doubt on both the efficacy of Neogene subaerial erosion and the concept of a Mio-Pliocene peneplain. He concluded (1981, p. 27): It is now abundantly clear that stratigraphic, sedimentological and morphological arguments all support the abandonment of the Mio-Pliocene peneplain concept and its replacement by a model in which Neogene subaerial denudation led to the stripping away of the Palaeogene cover and 
incision into the underlying Mesozoic rocks. Another erosion surface once attributed to marine trimming at the very end of the Neogene, named as the Calabrian transgression, was supposedly identified in southern England, particularly in the Chilterns and the North Downs, cutting across the Chalk (Wooldridge \& Linton 1955). However, later research cast serious doubts on the accuracy of this view. Moffat et al. (1986) showed that, although a bench existed, it was partly structural and partly due to a phase of marine erosion prior to the deposition of the Reading Beds and they concluded that It has no value as erosional evidence for a Plio-Pleistocene marine transgression (p. 105).

The key problem in reconstructing Neogene landscapes is the general scarcity of Neogene deposits onshore. Nonetheless, some evidence is available although the spatial and temporal coverage is inevitably patchy. In Scotland the gross topography of the Scottish Highlands can be attributed to pre-Quaternary times, chiefly to the Neogene (Hall 1991). In the shaping of relief both differential uplift of a palaeosurface of possible late Palaeogene age along a series of SW-NE trending Caledonian faults, including the Great Glen Fault (Le Coeur 1988, Ringrose \& Migoń 1997, Hall \& Bishop 2002), and Neogene etchplanation (Hall 1986, 1991) were involved. However, corresponding denudation was likely to be minor as indicated by the limited volume of deposits of Scottish provenance in the adjacent seas and their muddy rather than sandy character (Hall \& Bishop 2002).

Evidence for Neogene etchplanation is provided by the occurrence of weathering residuals of grus and sandy type, which are particularly frequent in the Eastern Highlands and the Buchan lowland (Fig. 4). They are convincingly demonstrated to pre-date the Quaternary (Hall 1986, 1991) and are associated with landforms of etched origin such as inselberg-like hills and intramontane basins (Hall 1991). Patches of grus weathering mantles are also present at higher altitudes, including the summit plateau of the Cairngorms (Sugden 1968, Hall 1996), showing its pre-Pleistocene inheritance. Tors on the summit surface might date to the end of the Neogene too (Ballantyne 1994). Finally, spectacular glacial breaches due to selective linear erosion such as the Lairig Ghru (Sugden 1968) incised

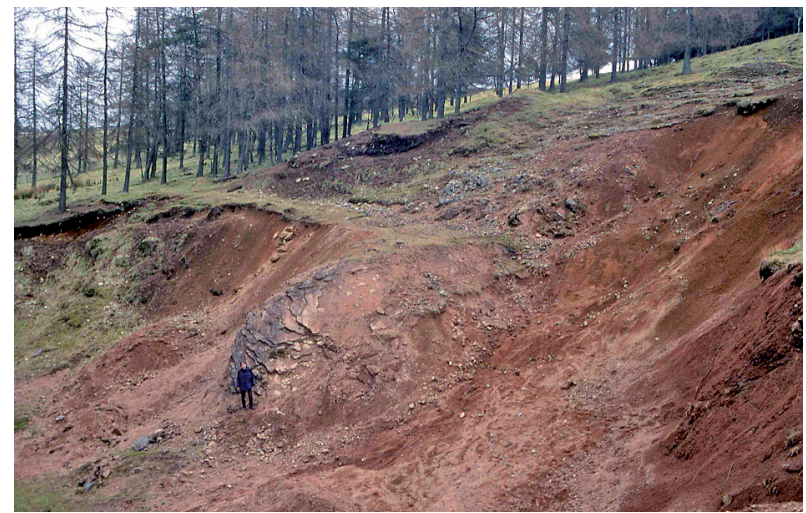

Fig. 4. Deeply weathered basement rocks in north-east Scotland (photo by Piotr Migoń).

into the hill-top surface add to the interpretation of the latter as an inherited pre-Pleistocene feature. However, in many other cases separation of effects of Neogene selective denudation and subsequent Pleistocene glacial erosion is hardly possible and alternative scenarios have been proposed, for example for the large intramontane basin of Rannoch Moor or the 'knock-and-lochan' topography which may be an exposed weathering front or a landscape due to efficient glacial scour (Thomas 1978).

In the south, a prominent landscape facet that dates back to the Neogene is the extensive 70-130 $\mathrm{m}$ a.s.l. surface which runs parallel to the coastline of Cornwall, Devon, south and west Wales (Fig. 5). However, contrasting interpretations have been offered as to its origin. Following the model presented by Wooldridge and Linton (1955), this surface was regarded as a Plio-Pleistocene marine bench (cf. Balchin 1952, Brunsden 1963). In fact, a series of benches has been identified along the coast and attributed to progressively lower transgressions in the Pliocene and Quaternary. This marine interpretation has been challenged by Walsh et al. $(1987,1999)$ who showed the presence of deeply weathered rock and Oligocene (Chattian) and Miocene sediments within this regional surface. Similarly, Battiau-Queney (1984) reports that deeply weathered rock (up to $20 \mathrm{~m}$ ) underlies this surface in Pembrokeshire in Wales. Both authors concur that this surface represents a mid- to late Cainozoic etchsurface rather than any surface of marine origin. The possible explanation of survival of this surface until recent times has been offered by Clayton \& Shamoon (1999). They suggest that Cornwall and south- 


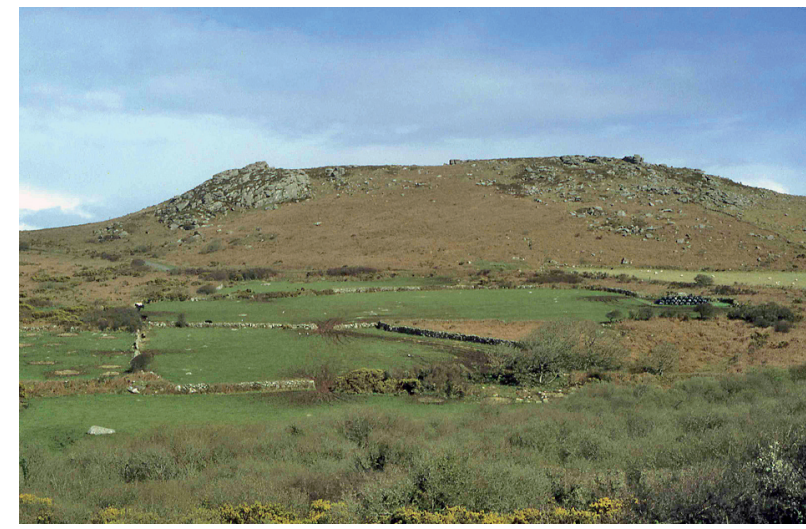

Fig. 5. Neogene palaeosurface in south-west England. The 70-130 m a.s.l. surface cut across metamorphic rocks in the foreground. The granite upland of Land's End is in the background (photo by Piotr Migoń).

west Wales are currently undergoing slow subsidence, caused by offshore water loading. By inference, these areas ought to have been subjected to modest uplift in glacial times, and such an up-and-down movement might be a long-term behaviour linked to sea level changes. The net effect would be a rather stable position, optimal for survival of old land surfaces, as also indicated by Battiau-Queney (1999).

The Neogene history of south-east England is still controversial (Jones 1999a, b). However, tectonic movements continuing throughout the Neogene were far more important than thought before and have led to the progressive compartmentalization of relief. The Weald was subjected to concurrent uplift and rock-controlled erosion, resulting in the large-scale inversion of relief (Fig. 6a). By contrast, the stable Chalklands around were long characterized by low relief and planation. Here, exhumation was an important component of landscape evolution. The low-lying part of the Chalk landscape, the Backslope Bench of Jones (1999a, p. 19), was subjected to marine transgressions during the Palaeogene (Eocene?) and the Pliocene, the latter leaving the Red Crag deposits (Mathers \& Zalasiewicz 1988). Both transgressions left a sedimentary cover of sand and clay which temporarily buried a pre-transgressive surface, providing effective protection against surface denudation (Fig. $6 b)$. Exhumation of the backslopes is of relatively recent date, Late Neogene to even Quaternary. One of the witnesses of exhumation is the 'clay-with-flint' deposit, once thought to be

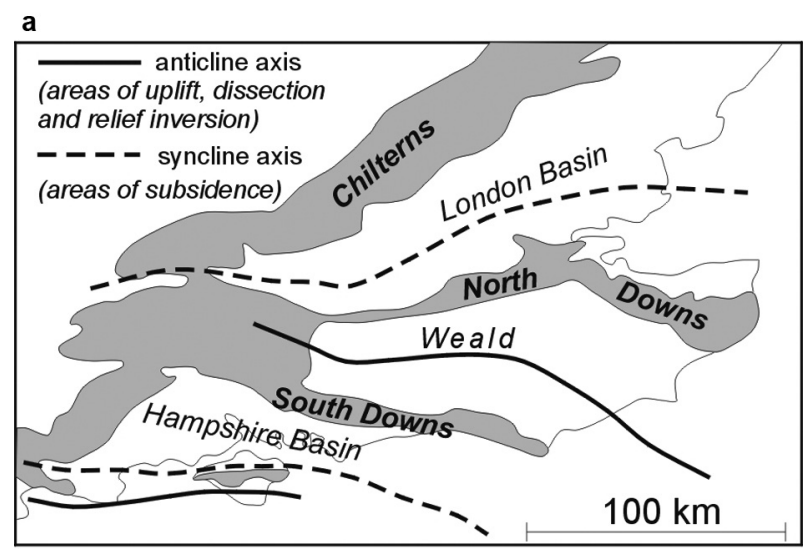

b

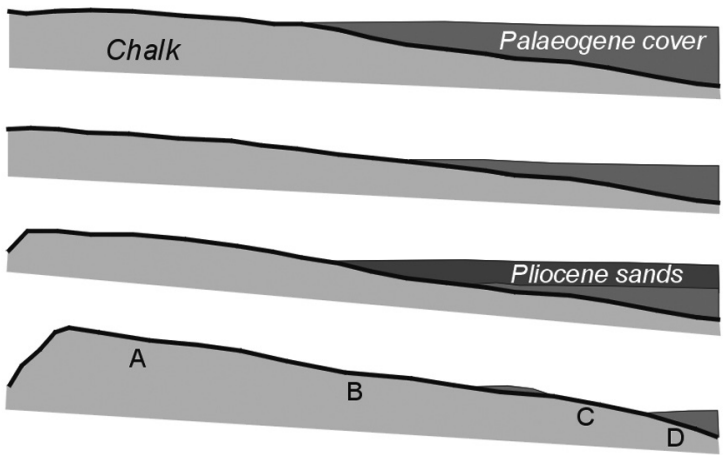

Fig. 6. Evolution of chalkland geomorphology (based on Jones, 1999a, b).

a) morphotectonics. Cretaceous chalk sediments survived on the flanks of the anticlines. b) origin of the multifaceted topography of chalk backslopes. A - chalk upland, moulded continuously by subaerial processes, B - 'backslope bench', exhumed and re-shaped by superficial processes, particularly in the cold climate of the Pleistocene, C - recently exhumed Palaeogene surface, D - buried Palaeogene surface.

a weathering residual remnant from the Tertiary (Wooldrigde \& Linton 1955), but later demonstrated to have originated at the boundary of Chalk and the overlying Palaeogene strata, i.e. at the sub-Palaeogene surface (Catt \& Hodgson 1976). Late Neogene to Quaternary uplift, possibly by as much as $200 \mathrm{~m}$, initiated incision and escarpment development, so moulding the Chalk terrain to its present-day form (Jones 1999b).

\section{The depth of denudation in the Cenozoic}

To calculate the importance of Cenozoic denudation, depths of Cenozoic denudation in the 
British Isles have been estimated using several independent methods. These include: apatite fission-track analysis (AFTA) and vitrinite reflectance (Green 1986, 2002, Lewis et al. 1992, Green et al. 1993), assessment of petrophysical properties of rocks, especially the degree of overcompaction (Hillis, 1995), interpretation of sediment volumes in adjacent basins (Hall, 1991, Clayton, 1996), history of unroofing of Tertiary igneous rocks (Emeleus 1991, Hall 1991) and calculation of solutional subsidence of calcareous rocks (Walsh et al. 1972). Further insights may be obtained from the analysis of inverted relief (cf. Hall 1987). Depending on the method used and data available, the estimates refer to various spans of geologic time.

The overall picture emerging from both the AFTA studies and degree of overcompaction of Mesozoic rocks is that of at least kilometre-scale erosion over much of Britain and adjacent shelf areas. Early estimates of 3-4 km of erosion over northern England (Green 1989, Lewis et al. 1992) were met with scepticism because they were inconsistent with independent geological evidence and most likely overestimated (cf. Holliday 1993). It has been suggested that more probable depths of erosion are $c .1 \mathrm{~km}$ onshore and up to $2 \mathrm{~km}$ offshore (Holliday 1993) and these figures broadly agree with estimates of denudation based on other petrophysical properties of rocks (Hillis 1995). Improvements in estimating palaeogeothermal gradients have resulted in a more realistic picture of long-term denudation, involving removal of c. $0.7 \mathrm{~km}$ of rock over the Lake District and 1.5-2 $\mathrm{km}$ in the costal plains (Green 2002; Fig. 7). Cenozoic denudation rates in Ireland were similar in magnitude, but highly variable spatially (Allen et al. 2002). Mountainous terrain in south-west Ireland and the north-central part appear to have undergone the highest denudation.

Rates of denudation varied over time, with much of the erosion having been accomplished in relatively brief periods. Most AFTA studies are suggestive of rapid cooling, and hence denudation, at the beginning of the Palaeogene, in response to rapid uplift events. A later episode of enhanced cooling in the Neogene has also been recognised, apparently caused by a new pulse of uplift (Green 1989; Lewis et al. 1992). Currently evidence accumulates that considerable uplift has affected southern England in the last 3 million years



Fig. 7. Differential depth of Cainozoic denudation over the Lake District (based on Green, 2002). C - Carboniferous sedimentary rocks.

and is recorded in fluvial terrace staircases along the major English rivers (Maddy et al. 2000).

Quantification of Cenozoic erosion in northern Scotland based on sediment volumes in the North Sea has been attempted by Hall (1991). A rough estimate of the thickness of eroded cover is $908 \mathrm{~m}$, but no allowance is made for an influx of material to the Scottish sector of the North Sea from more distant sources. Consequently, the figure given above is likely to be an overestimate. For the Palaeogene alone, which is now regarded as a main period of uplift and denudation in Scotland, the respective figure is $360 \mathrm{~m}$ (Hall 1991).

Denudation amounts given above are averaged over large areas and the validity of such spatial extrapolations is doubtful. This is particularly clear in the case of Scotland, where independent evidence for spatial variations in denudation exists. The igneous rocks belonging to the Tertiary Volcanic Province demonstrate rapid unroofing of Paleocene to Eocene granite masses (Emeleus 1991, Hall 1991). Unroofing of the plutonic complex in the Isle of Rhum required the removal of c. $2 \mathrm{~km}$ of overburden and this was accomplished during c. $2.8 \mathrm{ma}$. Clear evidence of massive erosion is provided by the presence of granite clasts within interbasaltic conglomerates. The total thickness of basaltic lavas eroded from eruptive centres amounts to $2 \mathrm{~km}$; in Mull the respective erosion happened between 58 and $56 \mathrm{Ma}$. These amounts of erosion require erosion rates of the order of $1 \mathrm{~km} / \mathrm{Ma}$ and certainly cannot be regarded as representative for the whole of Scotland (Hall 1991). Evidence for localised massive erosion is also known from the Bristol Channel, where the Lundy granite complex of Eocene age is exposed as an island. Unroofing of the Lundy granite is as- 
sociated with post-Oligocene uplift, and $c a .4 \mathrm{~km}$ of sediments had to be removed to expose the basement (Arthur 1989). However, as reviewed before, the adjacent onshore area in Cornwall and South Wales seems to have had very low rates of Neogene denudation (Battiau-Queney 1984, Walsh et al. 1999).

Scattered data on the amount of surface lowering towards the end of the Tertiary is provided by the present-day setting of allochthonic deposits in subsidence hollows in limestone terrains. Walsh et al. (1972) calculated amounts of lowering of Carboniferous limestone surfaces in the South Pennines using palaeobotanically dated Early Pliocene sediments, originally deposited on top of overlying shales, as a reference level. The lowering is recognised to have been from $126 \pm 15 \mathrm{~m}$ to 183 $\pm 45 \mathrm{~m}$ over the last 5-7 Ma, which would equal an average rate of denudation of 2-40 m/Ma. Solutional lowering has certainly taken place in other limestone areas and on Chalk surfaces (Brunsden et al. 1976, Summerfield \& Goudie 1980, Morawiecka et al. 1996), yet no evidence exists to allow one to calculate amounts and rates of denudation for this phase. Depths of latest Tertiary denudation may also be inferred from relief inversion. One of the places where such inversion has taken place is the Buchan surface in NE Scotland (Hall 1987). Fluvial gravels of presumed Pliocene age now occupy a watershed position, about $50 \mathrm{~m}$ above the present-day valley floors, indicating thereby minimum amounts of denudation. However, it is very probable that the inversion has happened within a deeply weathered land surface (Hall 1986). Both limestone bedrock and weathering mantles are probably characterised by their own distinctive intensities of denudation and the ascertained values may not be representative for other lithologies.

\section{Pre-Quaternary geomorphological legacy and tangible geoheritage of Britain}

An example of pre-Quaternary landscapes is provided by the existence of spreads of sarsen stones of presumed silcrete origin. These consist of isolated occurrences of quartzite boulders and also of major blockstreams in southern England (Summerfield \& Goudie, 1980; Fig. 3). The most spectacular examples of the blockstreams are those of the chalklands of Dorset, Wiltshire and Berkshire (Small et al., 1970). The sarsens have been mapped and described by Ullyott et al. (2004) and their mineralogy has been described by Ullyott \& Nash (2006). It is probable that most of the silcretes, which are analogous to features in the Paris Basin, formed at various times in the Neogene from groundwater and along ancient drainage lines. They suffered subsequent erosion and translocation by Quaternary frost weathering and solifluction.

Similarly, Neogene weathering and subsequent Quaternary modification have played a major role in the formation of the landscape of southwestern England, much of it is inherited. The recognition of the Neogene age of the 70-130 m surface (Fig. 5) has important implications for interpretation of adjacent granite uplands in Devon and Cornwall, including Dartmoor and Bodmin Moor. It is likely that their major topographic features had also been shaped in the Neogene and the periglacial modification during the Pleistocene, although visually evident, was relatively minor (Fig. 8). Rolling upland topography, with its famous tors and basins, would result from long-term differential denudation, accomplished mainly by deep weathering and stripping of saprolite (Linton 1955, Eden \& Green 1971, Green 1985). In particular, the mantle of grus weathering described thoroughly by Eden and Green (1971), which is present all over Dartmoor, would date back to the late Tertiary.

Another area where the major landscape features continue to tell the story of the pre-Quaternary is the Scottish Highlands, especially in the

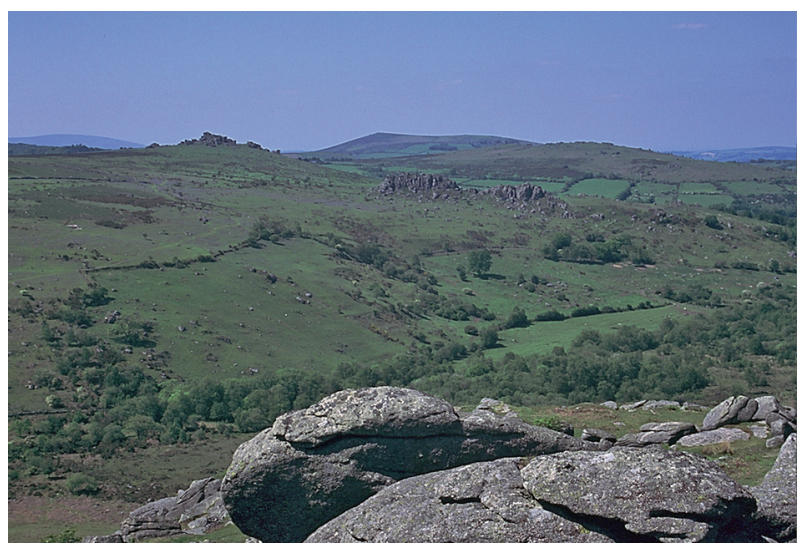

Fig. 8. Dartmoor upland with its characteristic tors (photo by Piotr Migoń). 




Fig. 9. The Cairngorms in Scotland serve as an excellent example of juxtaposition of old and new facets of relief.

The Pleistocene glacial trough of Loch Avon is incised into a gently rolling watershed surface, whose major relief features are inherited from preglacial times (photo by Piotr Migoń).

eastern part, where glacial erosion during the Pleistocene was less severe (Sugden 1968, Hall 1991). Two specific regions stand out. One is the lowland of Buchan in the east. It represents residual relief with plains, rock-controlled hills (inselbergs) and basins, jointly a product of long-lasting etchplanation. Weathering residuals of grus and clayey grus type are fairly common, providing evidence of Neogene inheritance. Hall (1987) does not even exclude the possibility that some inselbergs may be exhumed after the Chalk blanket was stripped and have survived until now in modestly modified form. By contrast, in the Cairngorms it is the striking summit surface of low relief that likely dates back to the Neogene. It is cut across granite, thus pointing to protracted planation, hosts numerous tors and exposes residual grus at a few localities. Glacial and periglacial landforms are evident but these are either discordant to an ancient upland, such as the glacial breaches and troughs (Fig. 9), or superimposed on the inherited planar landscape, such as block fields and solifluction sheets. However, arguing that tors on the summit planation surfaces are surviving pre-Quaternary elements too may be premature. Cosmogenic dating of tor surfaces indicates that currently observed forms began to emerge from regolith in the Middle Pleistocene (Hall \& Phillips 2006).

\section{Conclusions}

To understand and appreciate the diversity, nature and formation of some of the most striking landscapes of the British Isles it is important to recognize the significance of pre-Quaternary tectonic and climatic conditions. The landscape contains a palimpsest of features that have formed, particularly since the regression of the Cretaceous seas and the stripping of the Chalk cover. Ongoing tectonic movements, rejuvenation of ancient structures, igneous extrusive and intrusive activity, in conjunction with long-term erosion and weathering under relatively warm and humid conditions, combined to produce large parts of the area's Geoheritage.

\section{References}

Allen P.A., Bennett S.D., Cunningham M.J.M., Carter A., Gallagher K., Lazzaretti E., Galewsky J., Densmore A.L., Phillips W.E.A., Naylor D. \& Solla Hach C., 2002. The post-Variscan thermal and denudational history of Ireland. In: Doré A.G., Cartwright J.A., Stoker M.S., Turner J.P. \& White N. (eds), Exhumation of the North Atlantic Margin: Timing, Mechanisms and Implications for Petroleum Exploration. Geological Society Special Publication, 196: 371-399.

ANDERTON R., 2000. Tertiary events: the North Atlantic plume and Alpine pulses. In: Woodcock N.H. \& Strachan R.A. (eds), Geological History of Britain and Ireland. Blackwell Science, Oxford: 374-391.

Anderton R., Bridges P.H., Leader M.R. \& Sellwood B.W., 1979. A dynamic stratigraphy of the British Isles: a study in crustal evolution. Allen and Unwin, London.

Arthur M.J., 1989. The Cenozoic evolution of the Lundy Pull-Apart Basin into the Lundy Rhomb Horst. Geological Magazine, 126: 187-198.

BALCHIN W.G.V., 1952. Erosion surfaces of Exmoor and adjacent areas. Geographical Journal, 118: 453-476.

Ballantyne C.K., 1994. The tors of the Cairngorms. Scottish Geographical Magazine, 110: 54-59.

BAtTiaU-Queney Y., 1984. The pre-glacial evolution of Wales. Earth Surface Processes and Landforms, 9: 229-252.

Battiau-QuenEY Y., 1999. Crustal anisotropy and differential uplift: their role in long-term landform development. In: Smith B.J., Whalley W.B. \& Warke P.A. (eds), Uplift, Erosion and Stability: Perspectives on Long-term Landscape Development. Geological Society Special Publication, 162: 65-74.

Blundell D.J., 2002. Cenozoic inversion and uplift of southern Britain. In: Doré A.G., Cartwright J.A., Stoker M.S.,Turner J.P. \& White N. (eds), Exhumation of the North Atlantic Margin: Timing, Mechanisms and Implications for Petroleum Exploration. Geological Society Special Publication, 196: 85-101.

BRISTOW C.R., 1977. A review of the evidence for the origin of the kaolin deposits in SW England. Proceedings of the $8^{\text {th }}$ In- 
ternational Kaolin Symposium and Meeting on Alunite, Madrid \& Rome, K-2: 1-19.

BRISTOW C.R. \& EXLEY C.S., 1994. Historical and geological aspects of the China Clay industry of South-West England. Transactions, Royal Geological Society of Cornwall, 21: 247-314.

Brown E.H., 1979. The shape of Britain. Transactions, Institute of British Geographers, 48: 61-73

BRUNSDEN D., 1963. The denudation chronology of the river Dart. Transactions, Institute of British Geographers, 32: 4963.

Brunsden D. Doornkamp J.C., Green C.P. \& Jones D.K.C., 1976. Tertiary and Cretaceous sediments in solution pipes in the Devonian Limestone of South Devon, England. Geological Magazine, 113: 441-447.

BuchaRDT B., 1979. Oxygen isotope palaeotemperatures from the Tertiary period in the North Sea area. Nature, 276: 121-123.

BÜDEL J., 1957. Die "Doppelten Einebnungsflächen" in den feuchten Tropen. Zeitschrift für Geomorphologie N. F., 1: 201-228.

BuUman P., 1980. Palaeosols in the Reading Beds (Palaeocene) of Alum Bay, Isle of Wight, UK. Sedimentology, 27: 593-606.

CATt J.A. \& Hodgson J.M., 1976. Soils and geomorphology of the Chalk in south-east England. Earth Surface Processes, 1: 181-193.

Clayton K.M., 1953. The denudation chronology of part of the Middle Trent basin. Transactions, Institute of British Geographers, 19: 25-36.

Clayton K. \& Shamoon N., 1999. A new approach to the relief of Great Britain III. Derivation of the contribution of neotectonic movements and exceptional regional denudation to the present relief. Geomorphology, 27: 173-189.

COLLINSON M.E. \& HOOKER J.J., 1987. Vegetational and mammalian faunal changes in the early Tertiary of southern England. In: Friis E.M., Chaloner W.G. \& Crane P.R. (eds.), The Origins of Angiosperms and their Biological Consequences. Cambridge University Press, Cambridge: 259-304.

Cope J.C.W., 1994. A latest Cretaceous hotspot and the southeasterly tilt of Britain. Journal of the Geological Society, London, 151: 905-908.

Creber G.T. \& Chaloner W.G., 1985. Tree growth in the Mesozoic and early Tertiary and the reconstruction of palaeoclimates. Palaeogeography, Palaeoclimatology, Palaeoecology, 52: 35-60.

DALEY B., 1972. Some problems concerning the Early Tertiary climate of southern Britain. Palaeogeography, Palaeoclimatology, Palaeoecology, 11: 177-190.

DAvIS W.M., 1895. The development of certain English rivers. Geographical Journal, 5: 127-46.

DeWEY J.F. \& WindLeY B.F., 1988. Palaeocene-Oligocene tectonics of NW Europe. In: Morton A.C. \& Parson L.C. (eds.) Early Tertiary Volcanism and the Opening of the NE Atlantic. Geological Society Special Publication, 39: 25-31.

Durrance E.M., Bromley A.V., Bristow C.M., Heath M.J. \& Penman J.M., 1982. Hydrothermal circulation and postmagmatic changes in granites of south-west England. Proceedings of the Ussher Society, 5: 304-320.

EDEN M.J. \& GREEN C.P., 1971. Some aspects of granite weathering and tor formation. Geografiska Annaler, 53A: 92-99.

EdWARDS R.A. \& FRESHNEY E.C., 1982. The Tertiary sedimentary rocks. In: Durrance E.M. \& Laming D.J.C. (eds.), The Geology of Devon. University of Exeter, Exeter: 204-237.
Emeleus C.H., 1991. Tertiary igneous activity. In: Craig G.Y. (ed.), Geology of Scotland. Geological Society, London: 455-502.

Ford T.D., 1986. The evolution of the Castleton Cave Systems and related features, Derbyshire. Mercian Geologist, 10: 91-114.

Gale A.S., 2000. Late Cretaceous to Early Tertiary pelagic deposits: deposition on greenhouse Earth. In: Woodcock N.H. \& Strachan R.A. (eds.), Geological History of Britain and Ireland. Blackwell Science, Oxford: 356-373.

GREEN C.P., 1985. Pre-Quaternary weathering residues, sediments and landform development: examples from southern Britain. In: Richards K.S., Arnett R.R. \& Ellis S. (eds.), Geomorphology and Soils. Allen and Unwin, London: 58-77.

GREEN P.F., 1986. On the thermo-tectonic evolution of northern England: evidence from fission track analysis. Geological Magazine, 123: 493-506.

GreEN P.F., 1989. Thermal and tectonic history of the East Midlands shelf (onshore UK) and surrounding regions assessed by apatite fission track analysis. Journal of the Geological Society, London, 146: 755-773.

GreEN P.F., 2002. Early Tertiary paleo-thermal effects in Northern England: reconciling results from apatite fission track analysis with geological evidence. Tectonophysics, 349: 131-144.

Hall A.M., 1986. Deep weathering patterns in north-west Scotland and their geomorphological significance. Zeitschrift für Geomorphologie N. F., 30: 407-422.

Hall A.M., 1987. Weathering and relief development in Buchan, Scotland. In: Gardiner V. (ed.), International Geomorphology 1986, Part II. Wiley, Chichester: 991-1005.

Hall A.M., 1991. Pre-Quaternary landscape evolution in the Scottish Highlands. Transactions, Royal Society Edinburgh, Earth Science, 82: 1-26.

Hall A.M. 1996. The paleic relief of the Cairngorm Mountains. In: Glasser N.F. \& Bennett M.R. (eds.), The Quaternary of the Cairngorms. Field Guide. Quaternary Research Association, London: 13-27.

Hall A.M. \& Bishop P., 2002. Scotland's denudational history: an integrated view of erosion and sedimentation at an uplifted passive margin. In: Doré A.G., Cartwright J.A., Stoker M.S., Turner J.P. \& White N. (eds.), Exhumation of the North Atlantic Margin: Timing, Mechanisms and Implications for Petroleum Exploration. Geological Society Special Publication, 196: 271-290.

Hall A.M. \& Phillips W.M., 2006. Glacial modification of tors in the Cairngorm Mountains, Scotland. Journal of Quaternary Science, 21: 811-830.

HANCOCK J.M., 1975. The petrology of the Chalk. Proceedings Geologists' Association, 86: 499-536.

Hill I.G., Worden R.H. \& Meighan I.G., 2001. Formation of interbasaltic laterite horizons in NE Ireland by early Tertiary weathering processes. Proceedings Geologists' Association, 112: 339-348.

Hillis R.R., 1995. Regional Tertiary exhumation in and around the United Kingdom. In: Buchanan J.G. \& Buchanan P.G. (eds.), Basin Inversion. Geological Society Special Publication, 88: 167-190.

HolLIDAY D.W., 1993. Mesozoic cover over northern England: interpretation of apatite fission track data. Journal of the Geological Society, London, 150: 657-660.

IsAAC K.P., 1983. Tertiary lateritic weathering in Devon, England, and the Palaeogene continental environment of South-west England. Proceedings Geologists' Association, 94: 105-114. 
Jones D.K.C., 1981. Southeast and southern England. Methuen, London.

JoNES D.K.C., 1999a. Evolving models of the Tertiary evolutionary geomorphology of southern England with special reference to the Chalklands. In: Smith B.J.,Whalley W.B. \& Warke P.A. (eds.), Uplift, Erosion and Stability: Perspectives on Long-term Landscape Development. Geological Society Special Publication, 162, 1-23.

JONES D.K.C., 1999b. On the uplift and denudation of the Weald. In: Smith B.J., Whalley W.B. \& Warke P.A. (eds.), Uplift, Erosion and Stability: Perspectives on Long-term Landscape Development. Geological Society Special Publication, $162,25-43$

JONES O.T., 1931. Some episodes in the geological history of the Bristol Channel region. Report of the British Association for the Advancement of Science: 57-82.

Le Couer C., 1988. Late Tertiary warping and erosion in Western Scotland. Geografiska Annaler, 70A: 361-367.

Lewis C.L.E., Green P.F., Carter A. \& Hurford A.J., 1992. Elevated K/T palaeotemperatures throughout Northwest England: three kilometres of Tertiary erosion? Earth Planetary Science Letters, 112: 131-145.

LiNTON D.L., 1951. Midland drainage: some considerations bearing on its origin. Advancement of Science, 7(28): 449-56

LiNTON D.L., 1955. The problem of tors. Geographical Journal, 121: 470-487.

Maddy D., Bridgland D.R. \& Green C.P., 2000. Crustal uplift in southern England: evidence from the river terrace records. Geomorphology, 33: 167-181.

Mathers S J. \& Zalasiewicz J.A., 1988. The Red Crag and Norwich Crag formations of southern East Anglia. Proceedings Geologists' Association, 99: 261-278.

Moffatt A.J., Catt J.A., Webster R. \& Brown E.H., 1986. A reexamination of the evidence for a Plio-Pleistocene marine transgression on the Chiltern Hills. 1. Structures and surfaces. Earth Surface Processes and Landforms, 11: 95-106.

Morawiecka I., SLIPPer I. \& Walsh P., 1996. A palaeokarst of probable Kainozoic age preserved in Cambrian marble at Cemaes Bay, Anglesey, North Wales. Zeitschrift für Geomorphologie N. F., 40: 47-70.

NAdiN P.A., Kusznir N.J. \& Toth J., 1995. Transient regional uplift in the Early Tertiary of the northern North Sea and the development of the Iceland Plume. Journal of the Geological Society, London, 152: 953-958.

Newsome D. \& Dowling R., 2005. The scope and nature of geotourism. In: Dowling R.K. \& Newsome D. (eds.), Geotourism. Butterworth-Heinemann, Oxford: 3-25.

Ollier C.D., 1991. Ancient Landforms. Belhaven Press, London.

Rabassa J., Carignano C. \& Cioccale M., 2011. Gondwana paleosurafces in Argentina: an introduction. Geociências, 29(4): 439-466.

Reid E.M. \& Chandler M.E.J., 1933. The London Clay Flora. British Museum (Natural History), London.

Ringrose P.S. \& Migoń P., 1997. Analysis of digital elevation data from the Scottish Highlands and recognition of PreQuaternary elevated surfaces. In: Widdowson M. (ed.), Palaeosurfaces: Recognition, Reconstruction and Palaeoenvironmental Interpretation. Geological Society Special Publication, 120: 25-35.

SHEPPARD S.M.F., 1977. The Cornubian batholith SW England: $\mathrm{D} / \mathrm{H}$ and ${ }^{18} \mathrm{O} /{ }^{16} \mathrm{O}$ studies of kaolinite and other alteration minerals. Journal of the Geological Society, London, 133: 573-591.

Small R.J., 1970. The Study of Landforms. Cambridge University Press, Cambridge.
Small R.J., Clark M.J. \& LeWin J., 1970. The periglacial rock stream at Clatford Bottom, Marlborough Downs, Wiltshire. Proceedings of the Geologists' Association, 81: 87-98.

Sмith B.J. \& McAlister J.J., 1987. Tertiary weathering environments and products in north-east Ireland. In: Gardiner V. (ed.), International Geomorphology 1986, Part II. Wiley, Chichester: 1007-1031.

Sugden D.E., 1968. The selectivity of glacial erosion in the Cairngorm Mountains, Scotland. Transactions, Institute of British Geographers, 45: 79-92.

SumMERFIELD M.A. \& Goudie A.S., 1980. The sarsens of southern England. Their palaeoenvironmental interpretation with reference to other sediments. Institute of British $\mathrm{Ge}$ ographers, Special Publication, 11: 71-100.

Thomas M.F., 1978. Denudation in the tropics and the interpretation of the tropical legacy in higher latitudes - a view of the British experience. In: Embleton C.,Brunsden D. \& Jones D.K.C. (eds.), Geomorphology: Present Problems and Future Prospects. Oxford University Press, Oxford: 185202.

Twidale C.R., 1997. The great age of some Australian landforms: examples of, and possible explanation for, landscape longevity. In: Widdowson M. (ed.), Palaeosurfaces: Recognition, Reconstruction and Palaeoenvironmental Interpretation. Geological Society Special Publication, 120: 13-23.

UlLyOtT J.S. \& NASH D.J., 2006. Micromorphology and geochemistry of groundwater silcretes in the eastern South Downs, UK. Sedimentology, 53: 387-412.

Ullyott J.S., Nash D.J., Whiteman, C.A. \& Mortimore, R.N., 2004. Distribution, petrology and mode of the development of silcretes (sarsens and puddingstones) on the eastern South Downs, UK. Earth Surface Processes and Landforms, 29: 1509-1539.

VinCENT P., 1995. Limestone pavements in the British Isles: a review. Geographical Journal, 161: 265-274.

Walsh P.T., Boulter M.C., Istaba M. \& Urbani D.M., 1972. The preservation of the Neogene Brassington Formation of the Southern Pennines and its bearing on the evolution of upland Britain. Quarterly Journal of the Geological Society, London, 128: 519-59.

Walsh P.T. Atkinson V., Boulter M.C. \& Shakesby R.A., 1987. The Oligocene and Miocene outliers of west Cornwall and their bearing on the geomorphological evolution of Oldland Britain. Philosophical Transactions Royal Society, London, 323A: 211-245.

Walsh P., Boulter M. \& Morawiecka I., 1999. Chattian and Miocene elements in the modern landscape of western Britain and Ireland. In: Smith B.J., Whalley W.B. \& Warke P.A. (eds.), Uplift, Erosion and Stability: Perspectives on Long-term Landscape Development. Geological Society Special Publication, 162: 45-63.

Watts W.W., 1903. A buried Triassic landscape. Geographical Journal, 21: 623-636.

Wilson H.E., 1972. Regional Geology of Northern Ireland. HMSO, Belfast.

WoOLDRIDGE S.W., 1952. The changing physical landscape of Britain. Geographical Journal, 118: 297-308.

WoOldRidge S.W. \& LiNTON D.L., 1955. Structure, surface and drainage in south-east England. George Philip, London.

WRIGHT V.P., 1986. The polyphase karstification of the Carboniferous limestone in South Wales. In: Paterson K. \& Sweeting M. (eds.), New Directions in Karst. Geobooks, Norwich: 569-580. 